\title{
Diagnostic Model of Covid-19 for Resource-Limited Countries Based on The Combination Of Clinical Symptoms, Chest Radiography and Laboratory Test
}

Herikurniawan Herikurniawan ( $\nabla$ herikurniawan.dr@gmail.com )

University of Indonesia: Universitas Indonesia https://orcid.org/0000-0003-4073-0596

Martin C Rumende

Respirology and Critical illness Division : internal medicine department FKUI-RSCM

Siti Setiati

Clinical Epidemiology Unit : Internal Medicine Department FKUI-RSCM

July Kumalawati

Clinical Pathology Department FKUI-RSCM

Belinda Thania Deslanthy

faculty of medicine university of indonesia

Research article

Keywords: COVID-19, SARS-CoV 2, diagnostic model, scoring

Posted Date: December 3rd, 2020

DOl: https://doi.org/10.21203/rs.3.rs-119024/v1

License: (c) (i) This work is licensed under a Creative Commons Attribution 4.0 International License.

Read Full License 


\section{Abstract}

Background: COVID-19 is an infection caused by SARS-CoV 2. RT-PCR test is the gold standard for COVID-19 diagnosis, detecting the virus nucleic acid. However, this test is not yet available in every healthcare center, thus making the diagnostic process lengthy. A prompt diagnosis and immediate management are important to decrease mortality and morbidity rate, as well as to prevent transmission. A simple and practical diagnostic model using determinant factors is needed to guide the physician for a quicker decision-making.

Method: This study is a cross sectional study using consecutive sampling method. The study was conducted at RSUPN Cipto Mangunkusumo, Jakarta from March to June 2020. History of contact with COVID-19, clinical symptoms, laboratory examination, and chest radiographs data were taken from medical records. The steps of analysis were univariate, bivariate, and multivariate analyses, followed by ROC curve and Hosmer-Lemeshow calibration.

Result: There were 187 patients with the majority of subjects in the age group $<60$ years old $(65,2 \%)$ and male sex (53,47\%). The most frequent comorbidities were diabetes mellitus and hypertension. The selected variables in this scoring system were contact history, fever/history of fever, dyspnea with respiratory rate $>20$ breaths/minute, leucocyte $\leq 10.000 \mathrm{cel} / \mathrm{s} / \mathrm{mL}$ and typical chest radiography. The area under the curve for this model was 0,777 $(C l 95 \%(0,706-0,847), P<0,001)$. The probability was $82 \%$ with a cut-off point $\geq 4$, PPV: $74 \%$, NPV: $77 \%$.

Conclusion: Determinant model based on the combination of contact history, fever/history of fever, dyspnea, leucocyte $\leq 10.000 \mathrm{cells} / \mathrm{mL}$ and typical chest radiography provides a good accuracy to establish COVID-19 diagnosis.

\section{Background}

Coronavirus Disease 2019 (COVID-19) is an infection caused by severe acute respiratory syndrome coronavirus 2 (SARS-CoV-2). The World Health Organization (WHO) declared COVID-19 a pandemic in March 2020, as global cases had been increasing day by day. Until July 27th 2020, there had been over 16 million global cases of COVID-19, with Indonesia being one of the many countries with high number of cases. Everyday as of July 27th 2020, Indonesia has recorded more than one hundred confirmed cases with five thousand death cases. ${ }^{1}$

The approach of history taking, contact history, and ancillary test may be useful to diagnose COVID-19. The clinical symptoms may be varied and also atypical. Fever is the most common symptom. The other symptoms are respiratory symptoms (cough, dyspnea, rhinorrhea, and sore throat), systemic viral infection symptoms (malaise, myalgia, headache) and gastrointestinal symptoms (nausea, vomit, diarrhoea, abdominal pain). The ancillary tests for COVID-19 are haematology laboratory test and chest radiography. The haematology test in COVID-19 typically shows leucopenia, leucocytosis, lymphocytopenia, and increased neutrophil to lymphocyte ratio (NLR). In chest radiography, lesion such 
as infiltrate/opacity/consolidation with bilateral, peripheral distribution and a lower lobe predominance would typically be seen. ${ }^{3,4}$

The gold standard to diagnose COVID-19 is real-time polymerase chain reaction (RT-PCR). The problem with this diagnostic method, especially in countries with limited resources, is uneven laboratory setting hence uneven availability of the kit. These would delay diagnosis and result in suboptimal treatment. This study aimed to find the best diagnostic model by using a simple and widely available parameter, so that the final scoring system could be utilised in resource-limited setting.

\section{Method}

This study is a cross-sectional study using consecutive sampling methods. The inclusion criteria were COVID-19 suspected patients, aged $\geq 18$ years old, and treated at Cipto Mangunkusumo Hospital, Jakarta from March until June 2020. The exclusion criteria were patients who had incomplete laboratory test and chest radiography, suffered from an autoimmune disease (systemic lupus erythematosus, rheumatoid arthritis), chronic kidney disease stage $\mathrm{V}$, or severe hepatic disease. Variables which analized in this study are contact history, fever, respiratory symptoms, systemic viral infection symptoms, gastrointestinal symptoms, typical abnormality of chest radiography, leucocyte $(\leq 10.000 \mathrm{cel} / \mathrm{s} / \mu L)$, lymphocyte $(\leq 1.500$ cells $/ \mu L)$, NLR ( $\geq 5,8)$, C-reactive protein (CRP $\geq 5 \mathrm{mg} / \mathrm{L}$ ).

The definition of contact history is people with history of physical contact or in the same room (radius < $1 \mathrm{~m}$ ) with confirmed cases of COVID-19 without using standart personal protective equipment (PPE) within 2 days before onset until 14 days after onset. The definition of fever is body temperature $\geq 37,5^{0} \mathrm{C}$ at the first coming in admission or history of fever within 14 days before admission. The respiratory symptoms include cough, and/or dyspnea with frequency $>20$ breaths/minute, and/or sore throat and/or rhinorrhea. Systemic viral infection symptoms include headache and/or myalgia and/or malaise. Gastrointestinal symptoms include nausea and/or vomiting, and/or diarrhoea, and/or abdominal pain. The definition of typical abnormality of chest radiography is abnormality in chest radiography include infiltrate or opacity or consolidation with bilateral and peripheral distribution, predominant in lower lobes. Data was analysed using Statistical Product and Service Solution (SPSS) version 23.0 with univariate, bivariate, and multivariate analyses. Variables with $p<0,25$ from bivariate analysis were included in multivariate analysis. We used logistic regression technique to determine each variable's contribution to COVID-19 diagnosis. The scoring system was made by using coefficient (B) and standard error. The scoring system has also been tested with the receiver operating characteristics (ROC) curve and calibrated using the Hosmer-Lemeshow test.

\section{Results}

This study was conducted from March until June 2020. We included 282 patients, of which 95 patients were excluded (4 systemic lupus erythematosus patients, 2 hepatic cirrhosis patients, 3 stadium $V$ chronic kidney disease patients, and 86 patients with incomplete laboratory or chest radiography test). 
Hence, one hundred eighty-seven patients were analyzed. The majority of patients were older than 60 years old $(65,2 \%)$ and male (53,4\%) (See in Fig. 1A-B).

Hypertension (18,7\%) and diabetes mellitus (18,7\%) were the most common comorbid diseases (Fig. 1C). There were 70 COVID-19-confirmed cases. Confirmed cases are defined as cases with at least one positive RT-PCR result, whereas negative cases are defined as cases with at least two negative RT-PCR results See in Figs. 1D).

Fever and history of fever were reported in $65,2 \%$ patients. The most common respiratory symptom was cough $(72,2 \%)$ and the most common gastrointestinal symptoms was nausea $(23,5 \%)$ (See in Figs. 2 ). Leucocyte $\leq 10.000$ cells/uL was found in $51,9 \%$ of cases, Lymphocyte $\leq 1500$ cells/ $\mu \mathrm{L}$ in $73,3 \%$ of cases, NLR $\geq 5,8$ in $51,9 \%$ of cases and CRP $\geq 5 \mathrm{mg} / \mathrm{L}$ in $83,4 \%$ of cases. Typical abnormality of chest radiograph was shown in $20,9 \%$ of patients (See in Table 1). The variables from bivariate analysis with $p$ $<0,25$ were then included in multivariate analysis. After multivariate analysis, Some of variables with $p\rangle$ 0,05 were excluded from scoring.

Table 1

The ancillary test of subjects

\begin{tabular}{|ll|}
\hline Variable & $\mathbf{N}(\%)$ \\
\hline Chest Radiography & $39(20,9)$ \\
$\cdot$ Typical & $148(79,1)$ \\
$\cdot$ Atypical & \\
\hline Leucocyte, cells /uL & $97(51,9)$ \\
$\cdot \leq 10.000$ & $90(48,1)$ \\
$\cdot>10.000$ & \\
Lymphocyte, cells /uL & $137(73,3)$ \\
$\cdot<1500$ & $50(26,7)$ \\
$\cdot \geq 1500$ & \\
\hline NLR & $97(51,9)$ \\
$\cdot<5,8$ & $90(48,1)$ \\
$\cdot \geq 5,8$ & \\
\hline CRP (mg/L) & $31(16,6)$ \\
$\cdot<5$ & $156(83,4)$ \\
$\cdot \geq 5$ & \\
\hline
\end{tabular}


There were sore throat with Odds ratio $(\mathrm{OR}) 0,820 \mathrm{Cl} 95 \%(0,328-2,048), \mathrm{p}=0,671)$, Nausea $(\mathrm{OR} \mathrm{0,679} \mathrm{Cl}$ $95 \%(0,283-1,631), p=0,387)$, diarrhoea (OR 2,742 Cl 95\% (0,871-8,632), $p=0,085)$, myalgia ( OR 0,242 Cl $95 \%(0,046-1,268), p=0,093), \operatorname{NLR}($ OR 0,504 Cl 95\% (0,234-1,061), p =0,071), and CRP ( OR 0,803 Cl $95 \%(0,307-2,104), p=0,656)$. The contact history in the final model from multivariate analysis had odds ratio 8,673 (95\% Confidence Interval (Cl) 2,573-29,231) and $p<0,001$. Fever/history of fever had OR $1,658(95 \% \mathrm{Cl} 0,776-3,539)$ and $\mathrm{p}=0,192$; dyspnea had OR 2,708 (95\% Cl 1,141-6,503) and $\mathrm{p}=0,024$; leucocyte $\leq 10.000$ cells/uL had OR $2,381(95 \% \mathrm{Cl} 1,120-5,063)$ and $p=0,024$; typical chest radiography had OR 3,487 (95\% Cl 1,515-8,026) and $p=0,003$ (see in Table 2-3). Although fever was not statistically significant in the multivariate analysis, it is a clinically important factor that should not be disregarded when using the scoring system. 
Table 2

Analysis of clinical symptoms for diagnosis of COVID-19

\begin{tabular}{|c|c|c|c|c|c|}
\hline Variable & $\begin{array}{l}\text { COVID- } \\
19 \\
N(\%)\end{array}$ & $\begin{array}{l}\text { NON COVID- } \\
19 \\
\mathrm{~N}(\%)\end{array}$ & $\begin{array}{l}\mathrm{P} \\
\text { Bivariate }\end{array}$ & $\begin{array}{l}\mathrm{P} \\
\text { Multivariate }\end{array}$ & $\begin{array}{l}\text { OR } \\
\text { (Cl 95\%) }\end{array}$ \\
\hline $\begin{array}{l}\text { Contact History } \\
\text { Yes } \\
\text { No }\end{array}$ & $\begin{array}{l}18 \\
(81,8) \\
52 \\
(31,5)\end{array}$ & $\begin{array}{l}4(18,2) \\
113(68,5)\end{array}$ & $<0,001$ & $<0,001$ & $\begin{array}{l}8,673(2,573- \\
29,231)\end{array}$ \\
\hline $\begin{array}{l}\text { Fever/History } \\
\text { Fever } \\
\text { Yes } \\
\text { No }\end{array}$ & $\begin{array}{l}49 \\
(40,2) \\
21 \\
(32,3)\end{array}$ & $\begin{array}{l}73(59,8) \\
44(67,7)\end{array}$ & 0,185 & 0,192 & $1,658(0,776-3,539)$ \\
\hline $\begin{array}{l}\text { Cough } \\
\text { Yes } \\
\text { No }\end{array}$ & $\begin{array}{l}53 \\
(39,2) \\
17 \\
(24,3)\end{array}$ & $\begin{array}{l}82(60,8) \\
35(29,9)\end{array}$ & 0,255 & & \\
\hline $\begin{array}{l}\text { Dyspnea } \\
\text { Yes } \\
\text { No }\end{array}$ & $\begin{array}{l}16 \\
(47,0) \\
54 \\
(35,5)\end{array}$ & $\begin{array}{l}18(53,0) \\
99(64,5)\end{array}$ & 0,139 & 0,024 & $2,708(1,141-6,503)$ \\
\hline $\begin{array}{l}\text { Sore Throat } \\
\text { Yes } \\
\text { No }\end{array}$ & $\begin{array}{l}16 \\
(45,7) \\
54 \\
(35,5)\end{array}$ & $\begin{array}{l}19(54,3) \\
98(64,5)\end{array}$ & 0,176 & 0,671 & $0,820(0,328-2,048)$ \\
\hline $\begin{array}{l}\text { Rhinorrhea } \\
\text { Yes } \\
\text { No }\end{array}$ & $\begin{array}{l}6(30,0) \\
64 \\
(38,3)\end{array}$ & $\begin{array}{l}14(70,0) \\
103(61,7)\end{array}$ & 0,320 & & \\
\hline $\begin{array}{l}\text { Nausea } \\
\text { Yes } \\
\text { No }\end{array}$ & $\begin{array}{l}14 \\
(31,8) \\
56 \\
(39,1)\end{array}$ & $\begin{array}{l}30(68,2) \\
87(60,9)\end{array}$ & 0,243 & 0,387 & $0,679(0,283-1,631)$ \\
\hline $\begin{array}{l}\text { Vomiting } \\
\text { Yes } \\
\text { No }\end{array}$ & $\begin{array}{l}12 \\
(63,1) \\
58 \\
(37,1)\end{array}$ & $\begin{array}{l}19(36,9) \\
98(62,9)\end{array}$ & 0,512 & & \\
\hline
\end{tabular}




\begin{tabular}{|c|c|c|c|c|c|}
\hline Variable & $\begin{array}{l}\text { COVID- } \\
19 \\
N(\%)\end{array}$ & $\begin{array}{l}\text { NON COVID- } \\
19 \\
\text { N (\%) }\end{array}$ & $\begin{array}{l}\mathrm{P} \\
\text { Bivariate }\end{array}$ & $\begin{array}{l}\text { P } \\
\text { Multivariate }\end{array}$ & $\begin{array}{l}\text { OR } \\
\text { (CI 95\%) }\end{array}$ \\
\hline $\begin{array}{l}\text { Diarrhoea } \\
\text { Yes } \\
\text { No }\end{array}$ & $\begin{array}{l}11 \\
(55,0) \\
59 \\
(35,3)\end{array}$ & $\begin{array}{l}9(45,0) \\
108(64,5)\end{array}$ & 0,072 & 0,085 & $\begin{array}{l}2,742 \\
(0,871-8,632)\end{array}$ \\
\hline $\begin{array}{l}\text { Abdominal Pain } \\
\text { Yes } \\
\text { No }\end{array}$ & $\begin{array}{l}7(31,8) \\
63 \\
(38,1)\end{array}$ & $\begin{array}{l}15(68,2) \\
102(61,9)\end{array}$ & 0,371 & & \\
\hline $\begin{array}{l}\text { Myalgia } \\
\text { Yes } \\
\text { No }\end{array}$ & $\begin{array}{l}3(20,0) \\
67 \\
(38,9)\end{array}$ & $\begin{array}{l}12(80,0) \\
105(61,1)\end{array}$ & 0,118 & 0,093 & $0,242(0,046-1,268)$ \\
\hline $\begin{array}{l}\text { Headache } \\
\text { Yes } \\
\text { No }\end{array}$ & $\begin{array}{l}7(31,8) \\
63 \\
(38,1)\end{array}$ & $\begin{array}{l}15(68,2) \\
102(61,9)\end{array}$ & 0,371 & & \\
\hline $\begin{array}{l}\text { Malaise } \\
\text { Yes } \\
\text { No }\end{array}$ & $\begin{array}{l}24 \\
(36,3) \\
46 \\
(38,0)\end{array}$ & $\begin{array}{l}42(63,4) \\
75(62,0)\end{array}$ & 0,476 & & \\
\hline
\end{tabular}


Table 3

Analysis of ancillary tests for diagnosis of COVID-19

\begin{tabular}{|c|c|c|c|c|c|}
\hline Variable & $\begin{array}{l}\text { COVID- } \\
19 \\
N(\%)\end{array}$ & $\begin{array}{l}\text { NON COVID- } \\
19 \\
\text { N (\%) }\end{array}$ & $\begin{array}{l}\mathrm{P} \\
\text { Bivariate }\end{array}$ & $\begin{array}{l}\mathrm{P} \\
\text { Multivariate }\end{array}$ & $\begin{array}{l}\text { OR } \\
\text { (CI 95\%) }\end{array}$ \\
\hline Chest Radiography & $21(53,8)$ & $18(46,2)$ & 0,015 & 0,003 & \multirow{6}{*}{$\begin{array}{l}3,487(1,515- \\
8,026) \\
2,381(1,120- \\
5,063)\end{array}$} \\
\hline Typical & $49(33,1)$ & $99(66,9)$ & \multirow[t]{5}{*}{$<0,001$} & \multirow[t]{5}{*}{0,024} & \\
\hline Atypical & $50(51,5)$ & $47(48,5)$ & & & \\
\hline $\begin{array}{l}\text { Leucocyte ( } \\
10.000)\end{array}$ & $20(22,2)$ & $70(77,8)$ & & & \\
\hline \multirow{2}{*}{\multicolumn{3}{|c|}{ Yes }} & & & \\
\hline & & & & & \\
\hline \multirow{2}{*}{$\begin{array}{l}\text { Lymphocyte ( } \\
\text { 1.500) }\end{array}$} & $49(35,7)$ & $88(64,3)$ & 0,270 & 0,071 & \multirow{2}{*}{$\begin{array}{l}0,504(0,234- \\
1,061)\end{array}$} \\
\hline & $21(42)$ & $29(58)$ & $<0,001$ & \multirow[t]{6}{*}{0,656} & \\
\hline $\mathrm{Nh}$ & $24(24,7)$ & $73(75,3)$ & \multirow[t]{5}{*}{0,058} & & \multirow{5}{*}{$\begin{array}{l}0,803(0,307- \\
2,104)\end{array}$} \\
\hline NII $P(>58)$ & $46(51,1)$ & $44(48,9)$ & & & \\
\hline $\operatorname{NLT}(=0,0)$ & $54(34,6)$ & $102(65,4)$ & & & \\
\hline res & $16(51,6)$ & $15(48,4)$ & & & \\
\hline No & & & & & \\
\hline \multicolumn{6}{|l|}{$\operatorname{CRP}(\geq 5)$} \\
\hline \multicolumn{6}{|l|}{ Yes } \\
\hline No & & & & & \\
\hline
\end{tabular}

From the multivariate analysis, we created a score for each variable. Contact history with confirmed COVID-19 patient is worth 3 points, fever/history of fever 1 point, dyspnea with respiratory rate 20 breaths/minute 2 points, leucocyte $\leq 10.000$ cells/uL 2 points and typical chest radiography 2 points. The total score is 10 points (see in Table 4). 
Table 4

C-Covid Score (Clinical Covid Score)

\begin{tabular}{|llc|}
\hline Variable & Assesment & Score \\
\hline Contact History with COVID-19 & Yes & 3 \\
\hline Fever $\geq 37,5 /$ Fever History & Yes & 1 \\
\hline Dyspnea (RR > 20 breaths/minute) & Yes & 2 \\
\hline Leucocyte ( $\leq 10.000 /$ uL) & Yes & 2 \\
\hline $\begin{array}{l}\text { Typical Chest Radiography } \\
\text { (Infiltrat/Opacity/Consolidation with bilateral, peripheral, and lower zone }\end{array}$ & Yes \\
\hline predominant) & & \\
\hline Sotal & & 10 \\
\hline Suspect COVID 19: (Probability 82\%), PPV 74\% NPV 77\% & & \\
\hline
\end{tabular}

From the ROC curve analysis, the area under the curve is 0,77 with a cut-off point of 4 (see in Figs. 3 ). The diagnostic value for a scoring system with a cut-off point of 4 is as follows: $57,14 \%$ sensitivity; $88,03 \%$ specificity; 74,00\% Positive predictive value (PPV); 77,00\% Negative predictive value (NPV); and 4,77, likelihood ratio (LR+); with diagnosis probability of $82 \%$ (see in Figs. 4).

\section{Discussion}

This was the first study in Indonesia to create a diagnostic scoring system for COVID-19. The majority of patients in our study were aged $<60$ years old and male. These groups are at an increased risk for SARSCoV-2 infection due to their high mobility hence exposure to the virus. These results are similar to those of Huang et al. and Song et al. Their studies showed that adults at productive age, especially male, had the largest percentage of infection..$^{5,6}$ The most common comorbidities in this study were diabetes mellitus $(18,7 \%)$ and hypertension $(18,7 \%)$. Uncontrolled diabetes mellitus is a predictor of deterioration and death for some viral infection. Patients with hypertension treated with antihypertensive medication which induces receptor Angiotensin converting enzyme-2 (ACE-2) expression are at an increased risk of infection as well, although this theory remains controversial. 6,7

Contact history was one important determining factor in this study. Multivariate analysis showed that contact history was statistically significant with OR 8,673 (CI 95\% 2,573-29,231, p<0,001). The primary transmission mechanism of SARS-CoV-2 is through droplets. Droplets from coughing, sneezing or talking may occur within $<1$ meter distance. This theory is reinforced by a study from Chu et al, who showed that physical distancing over 1 meter has a better protective effect than $<1 \mathrm{~m}$ with OR $0,18 .^{8}$ 
SARS-CoV-2 will stay in fomites (contaminated object or environment): for 2 hours in plastic and stainless steel, 4 hours in copper and 24 hours in carton. Based on this fact, physical distancing and personal hygiene are recommended to prevent viral transmission. ${ }^{9} \mathrm{~A}$ study by Van Doramalen et al. reported that SARS-CoV-2 would live in aerosol nebulizer at least for 3 hours; and to 16 hours long in another study. Therefore, airborne transmission may occur. The growing evidence that supports droplets as well as airborne particles as the transmission mechanism of SARS-CoV-2 emphasises that contact history in suspected patients is imperative.

Dyspnea was statistically significant in this study with OR 2,708 (CI 95\% (1,141-6,503), p = 0,024). Song, et all also reported that dyspnea was significant for diagnosis COVID-19. ${ }^{5}$ Dyspnea are not as frequent as fever or cough. This may happen because dyspnea appear after 3 days of onset. Although the frequency of dyspnea is not very frequent, but dyspnea is the most common symptoms which bring patient to the hospital. In this study, we combine subjective symptoms of dyspnea and objective assesment using tachypnea (> 20 breaths/minutes) so it will be more spesific for helping diagnosis COVID-19.

Fever was not statistically significant, but it is clinically important, so we still included fever for our scoring. In fact, fever is the most common symptom in COVID-19. A meta-analysis from Cao et al. reported that fever occurred in $87,3 \%$ of patients. Dyspnea was reported in $18,2 \%$ of COVID-19 patients and it was statistically significant with OR 2,708 $(\mathrm{Cl} 95 \%(1,141-6,503), \mathrm{p}=0,024) .{ }^{10}$ There were also a few patients complaining of dyspnea after three days of infection. In practice, dyspnea is the most frequent symptoms which brings patients to the hospital.

Leucocyte $\leq 10.000$ cells/ $\mu \mathrm{l}$ was one of the variables which was statistically significant with $\mathrm{OR} 2,381$ (Cl $95 \%(1,120-5,063), p=0,024)$. Several studies reported a wide variety of abnormal leucocyte in COVID-19 patients, both leucopenia and leucocytosis. Normal leucocyte or lower (leucopenia) usually happens in the initial stage of infection. Sun et al. reported that confirmed COVID-19 patients had lower leucocyte than the non-COVID-19 patients $(p<0,001) \cdot{ }^{11-13}$

Lymphopenia (absolute lymphocyte count $(\mathrm{ALC})<1500$ cells $/ \mu \mathrm{L}$ ) was not statistically significant in this study with prevalence risk 0,852 (CI 95\% 0,573-1,265,p=0,270). In the initial stage of SARS-CoV-2 infection, lymphocyte may be normal. As severity increases, lymphocyte would decrease, so it actually makes lymphocyte an excellent indicator of the severity of COVID-19, but not for diagnosis COVID-19. Mardani, et all and Song, et all also reported no significant relation between lymphocyte and diagnosis COVID-19. A systematic review from Huang et al. reported that COVID-19 patients had three times the risk for adverse outcomes if they had had leucocytes $<1.100$ cells $/ \mu L .{ }^{14}$

Increased NLR $(\geq 5,8)$ was also not statistically significant in this study. This result is contradictive with Song et al. Changes in NLR indicates a systemic inflammatory condition caused by the patient's immune system. Patients with severe symptoms usually would have high NLR, whereas those with mild symptoms would exhibit low NLR. Our patients had mild-moderate symptoms which was the reason why the increased NLR was not significant. ${ }^{5}$ 
$\mathrm{CRP} \geq 5 \mathrm{mg} / \mathrm{dL}$ was statistically significant in this study. This result is similar to Ferrari et al. Some studies have indeed reported increased CRP in COVID-19 patients. However, this protein is not an adequate diagnostic marker because of its low specificity for COVID-19. A study by Wang et al. showed an increase in CRP following a lung lesion in COVID-19. Therefore, CRP is a more effective as an indicator for prognosis rather than for diagnosis of COVID-19.15,16

Typical abnormality in chest radiography occurred in $20,9 \%$ of the subjects. As much as $53,8 \%$ from those groups were confirmed cases of COVID-19. The result from multivariate analysis showed statistically significant association with OR 3,487 (CI95\% (1,515-8,026), p = 0,003), as supported by Wong et al, who described a typical abnormality of COVID-19 as multifocal consolidation or opacity with bilateral distribution in the peripheral and lower lobe of the lungs., ${ }^{4,17}$ Cozy et al. described opacities or reticular nodular consolidation with bilateral, peripheral distribution and lower zone predominance as typical radiograph lesion in COVID-19. This lesion is caused by activation of ACE-2 receptors, which are expressed more in pneumocytes located distally. This provides evidence that SARS-CoV2 tends to infect the distal areas. ${ }^{18,10}$

Our scoring system consists of 5 variables: contact history with COVID-19 patients (3 points), fever/history of fever ( 1 point), dyspnea with respiratory rate $>20$ breaths/minute ( 2 points), leucocyte $\leq$ 10.000 cells/uL ( 2 points) and typical chest radiography ( 2 points). The total score is 10 points. ROC analysis revealed $A U C=0,77$ for a cut-off $\geq 4$. Hence, we recommend using a cut-off point $>4$ for the score and as importantly, taking into account the clinical symptoms. This scoring system has been tested to have $57,14 \%$ sensitivity, 88,03\% specificity, 77\% NPV, 74\% PPV, 4,77 LR+, 0,48 LR- and 82\% probability in establishing the COVID-19 diagnosis. Calibration test for this scoring using the Hosmer and Lemeshow Test resulted in $p=0,590$ which means this scoring has good validation.

\section{Conclusion}

This diagnostic model, taking into consideration contact history, fever/history of fever, dyspnea with respiratory rate $>20$ breaths/minute, leucocyte $\leq 10.000$ cells/ $\mu \mathrm{L}$ and typical chest radiography, provides a satisfactory diagnostic value to confirm the diagnosis of COVID-19.

\section{Abbreviations}

COVID-19 : Coronavirus Disease 2019; SARS-CoV-2 : Severe Acute Respiratory Syndrome-Coronavirus-2; WHO : World Health Organization; NLR : Neutrophil to lymphocyte ratio; RT-PCR : Reverse transcription polymerase chain reaction; PPE : Personal protective equipment; ROC : Receiver operating characteristics; SPSS : Statistical Product and Service Solution; OR : Odds ratio; Cl : Confidence interval; CRP : C-reactive protein; PPV : Positive predictive value; NPV : Negative predictive value; LR : Likelihood ratio; ACE-2 : Angiotensin converting enzyme-2; ALC : Absolute lymphocyte count.

\section{Declarations}




\section{Ethics approval and consent to participate}

The data were taken from medical records thus we didn't need inform consent from all the participants. This study was approved by the Institutional Review board at University of Indonesia, reference number: KET-576/UK2.F1/ETIK/PPM.00.02/2020.

\section{Consent for publication}

Not applicable.

\section{Availability of data and materials}

Institutional policy does not allow sharing of data and materials publicly.

\section{Competing interest:}

The authors declare no competing interest.

\section{Funding:}

Not applicable.

\section{Author's contribution}

$\mathrm{H}, \mathrm{MR}, \mathrm{SS}, \mathrm{JK}$, and BD contributed to the design and implementation of the concept.

$\mathrm{H}$ and $\mathrm{BD}$ contributed equally to this work. $\mathrm{H}$ and $\mathrm{BD}$ contributed on collect and analyze patient data. MR, SS, and JK contributes to the evaluation. H, MR, SS, JK, and BD contributed to the search for scientific literature. $\mathrm{H}$ and $\mathrm{BD}$ contributed to the statistical

analysis of the data. All authors contributed for writing and reviewing papers. All authors read and agree the last manuscript.

\section{Acknowledgments}

Not applicable.

\section{References}

1. Kementerian Kesehatan Republik Indonesia. Situasi terkini infeksi corona. [2020] cited on 28 April 2020. available from https://covid19.kemkes.go.id/category/situasiinfeksiemerging/infocoronavirus/\#.XrihXcAxXIU.

2. Burhan E, Isbaniah F, Susanto AD, Aditama TY, Soedarsono, Sartono TT, et al. Pedoman Pencegahan dan Pengendalian Corona Virus Disease (COVID-19). Jakarta: Kementerian Kesehatan RI, DirJen P2P”; 2020. 
3. Ozma MA, Maroufi P, Khodadadi E, Kose S, Esposito I, Ganbarov K, et al. Clinical manifestation, diagnosis, prevention and control of SARS-CoV-2 (COVID-19) during the outbreak period. Infez Med. 2020;28(2):153-65.

4. Wong HYF, Lam HYS, Fong AH, Leung ST, Chin TW, Lo CSY, et al. Frequency and Distribution of Chest Radiographic Findings in COVID-19 Positive Patients. Radiology. 2019:201160.

5. Song CY. HJ, Lu YQ. COVID-19 early warning score: a multi-parameter screening tool to identify highly suspected patients. MedR/v. 2020.

6. Huang D, Wang T, Chen Z, Yang H, Yao R, Liang Z. A novel risk score to predict diagnosis with Coronavirus Disease 2019 (COVID-19) in suspected patients: A retrospective, multi-center, observational study. 2020. doi:10.1002/jmv.26143.

7. Hussain A, Bhowmik B, moreira NCdv. COVID-19 and diabetes: Knowledge in progress. Diabetes Res Clin Pract. 2020. doi:10.1016/j.diabres.2020.108142.

8. Chu Dk, AkI EA, Duda S, Solo K, Yaacoub S, Schunemann HJ. Physical distancing, face masks and eye protection to prevent person to person transmission of SARS-CoV-2 and COVID-19: a systematic review and meta-analysis. Thelancetcom. 2020.

9. Doremalen NV, Bushmaker T, Munster VJ. Aerosol and surface stability of SARS-CoV-2 as Compared with SARS-CoV-1. N Engl J Med. 2020. doi:10.1056/NEJMc2004973.

10. Cao Y, Liu X, Xiong L, Cai K. Imaging and clinical features of patients with 2019 novel coronavirus SAR-CoV2: A Systematic review and meta-analysis. J Med Virol. 2020. doi:10.1002/jmv.25822.

11. Tan L, Wang Q, Zhang D, Ding J, Huang Q, Tang Y-Q. Lymphopenia predicts disease severity of COVID-19: A descriptive and predictive study. Signal transduction and targeted therapy. 2020;5.

12. Pascutti MF, Erkelens MN, Nolte MA. Impact of Viral Infections on Hematopoiesis: From Beneficial to Detrimental effects on Bone Marrow Output. Front Immunol. 2020;7.

13. Sun S, Cai X, Wang H, He G, Lin Y, Lu B. Abnormalities of peripheral blood system in patients with COVID-19 in Wenzhou, China. Clin Chim Acta. 2020;507:174-80.

14. Huang G, Kovalic AJ, Grabber CJ. Prognostic Value of Leukocytosis and Lymphopenia for Coronavirus Disease Severity. Emerg Infect Dis. 020;26.

15. Wang G, Wu C, Zhang Q, Wu F, Yu B, Lv J, et al. C reactive protein level may predict the risk of COVID19 aggravation. 2020.

16. Matsumoto H, Kasai T, Sato A, Ishiwata S, Yatsu S, Shitara J. Association between C-reactive protein levels at hospital admission and long-term mortality in patients with acute decompensated heart failure. Springer Japan KK. 2019.

17. Brenneis R, Yu Y, Vaughan S. COVID-19 (corona virus disease 2019): Pathophyisiology and Clinical Findings. Thecalgaryguidecom. 2020.

18. Schiaffino S, Tritella S, Cozzi A, Carriero S, Blandi L, Ferraris L. Diagnostic performance of chest x-ray for COVID-19 pneumonia during the SARS-CoV-2 pandemic in Lombardy, Italy. J Thorac Imaging. 2020;00. 
19. Mason RJ. Pathogenesis of COVID-19 from a cell biologic perspective. European Respiratory Journal. 2020.

\section{Figures}
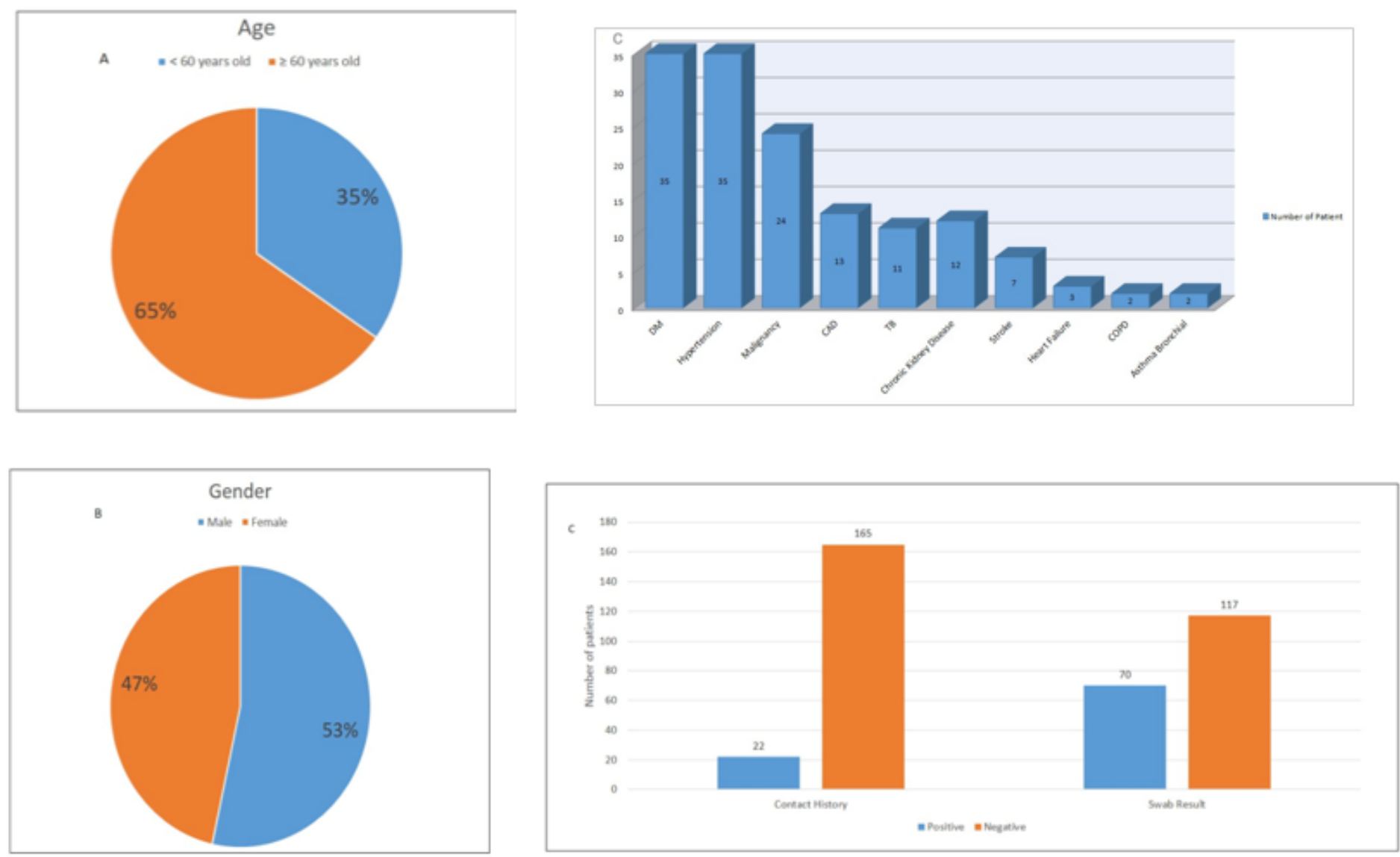

Figure 1

Demographic characteristics of subjects. (A). Age (B). Gender (C). Comorbid factor (D). Swab result and contact history 

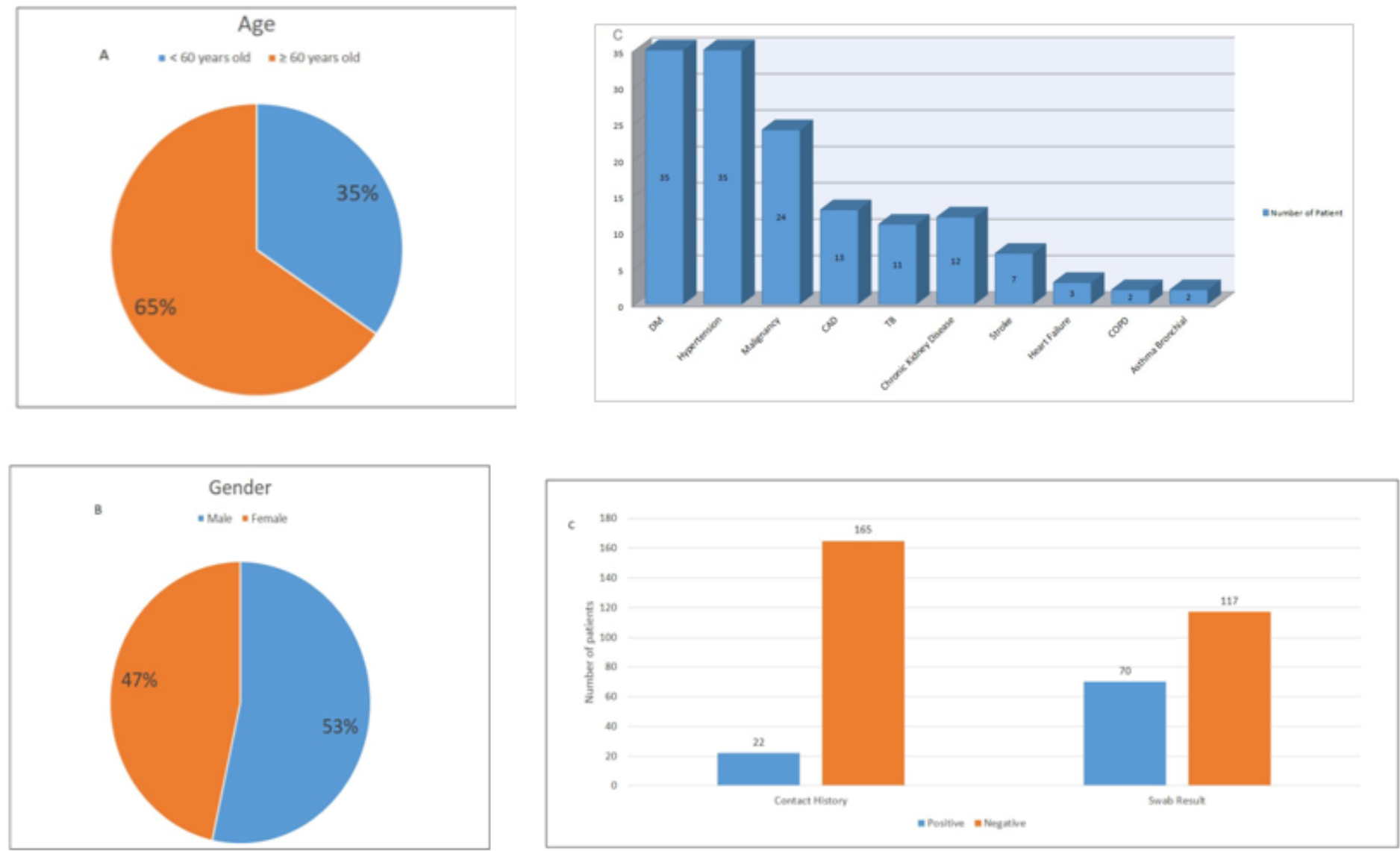

\section{Figure 1}

Demographic characteristics of subjects. (A). Age (B). Gender (C). Comorbid factor (D). Swab result and contact history 


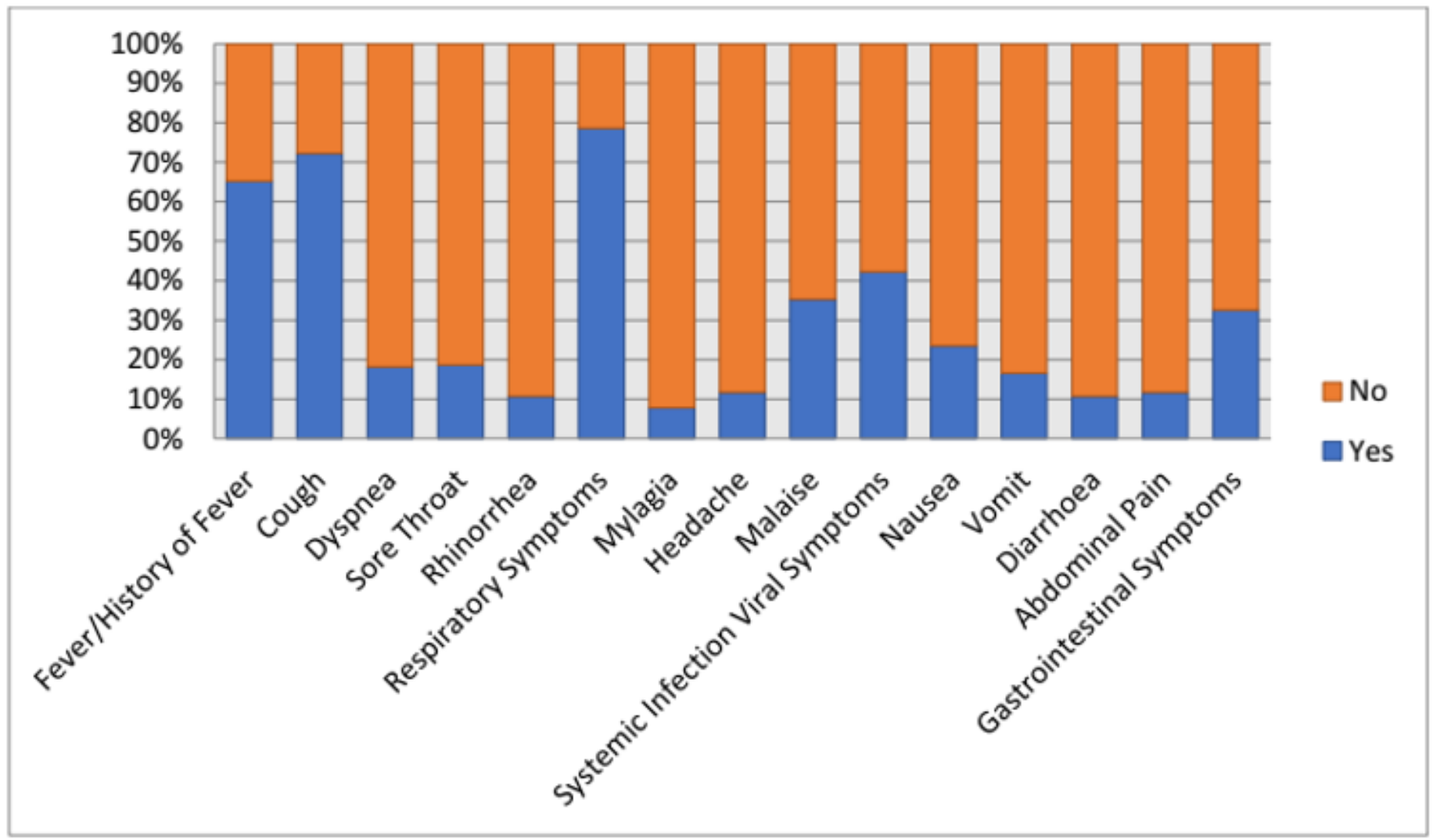

Figure 2

Subject clinical symptoms characteristics 


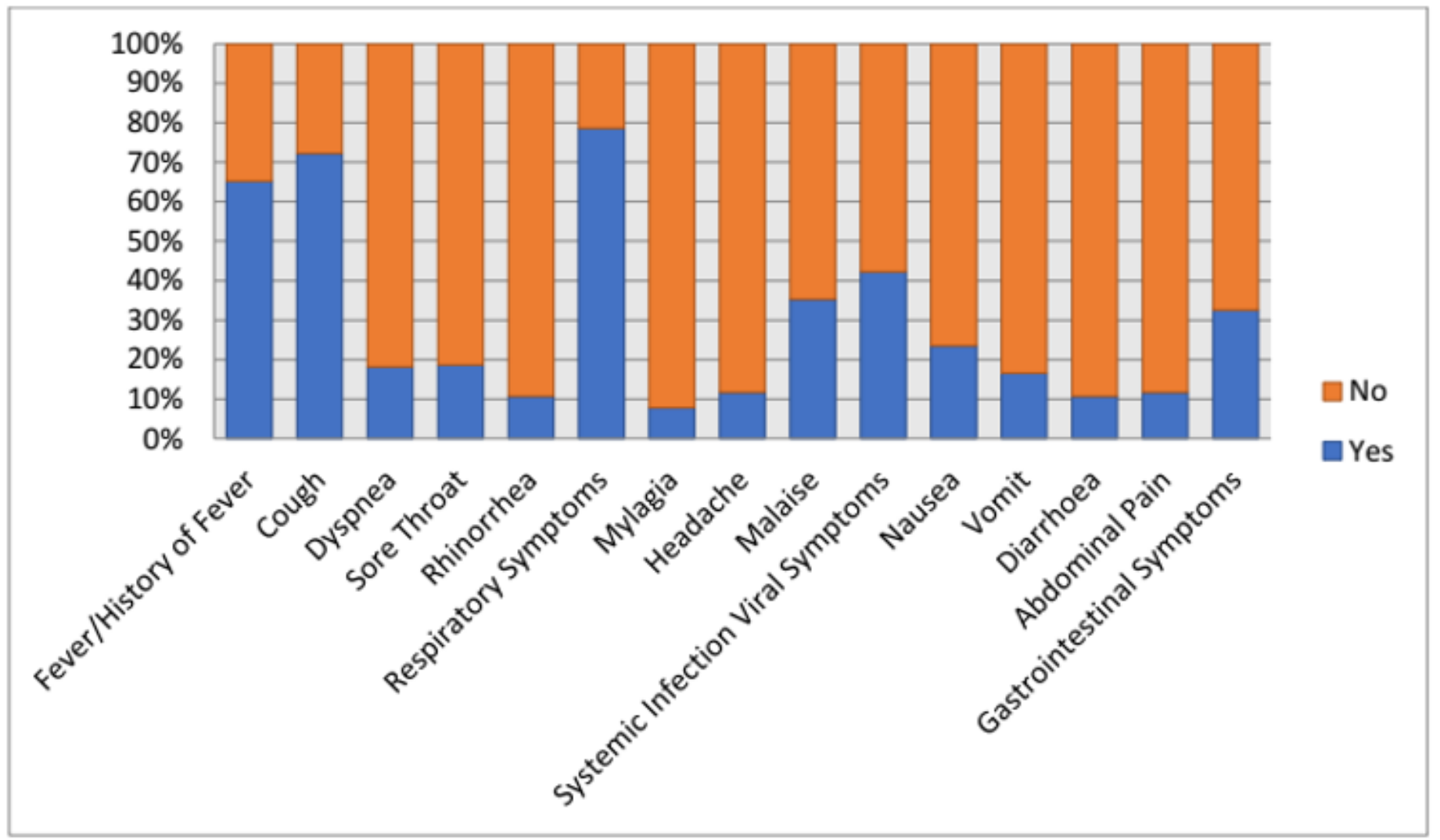

Figure 2

Subject clinical symptoms characteristics 


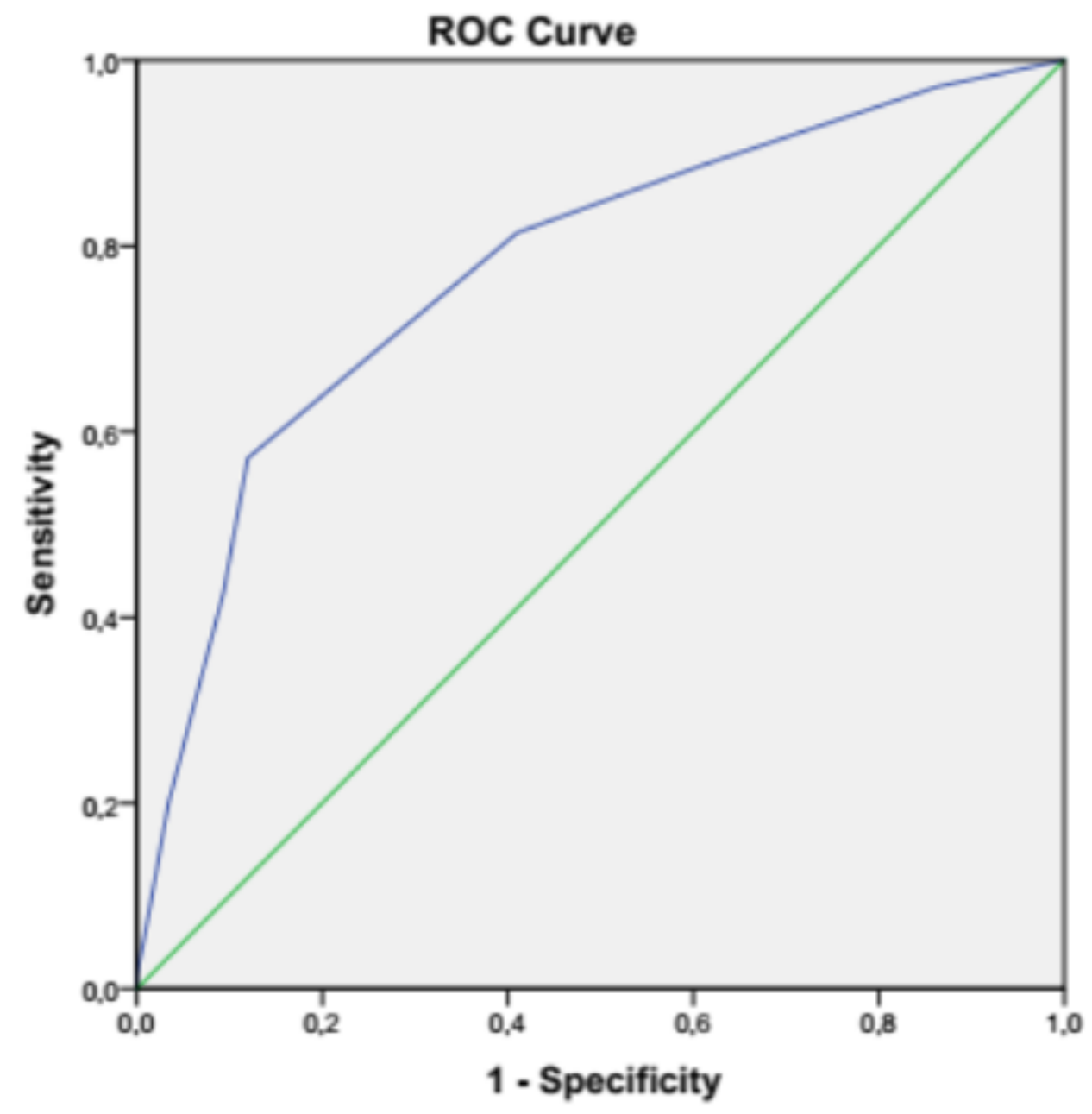

Figure 3

ROC curve of the scoring system. 


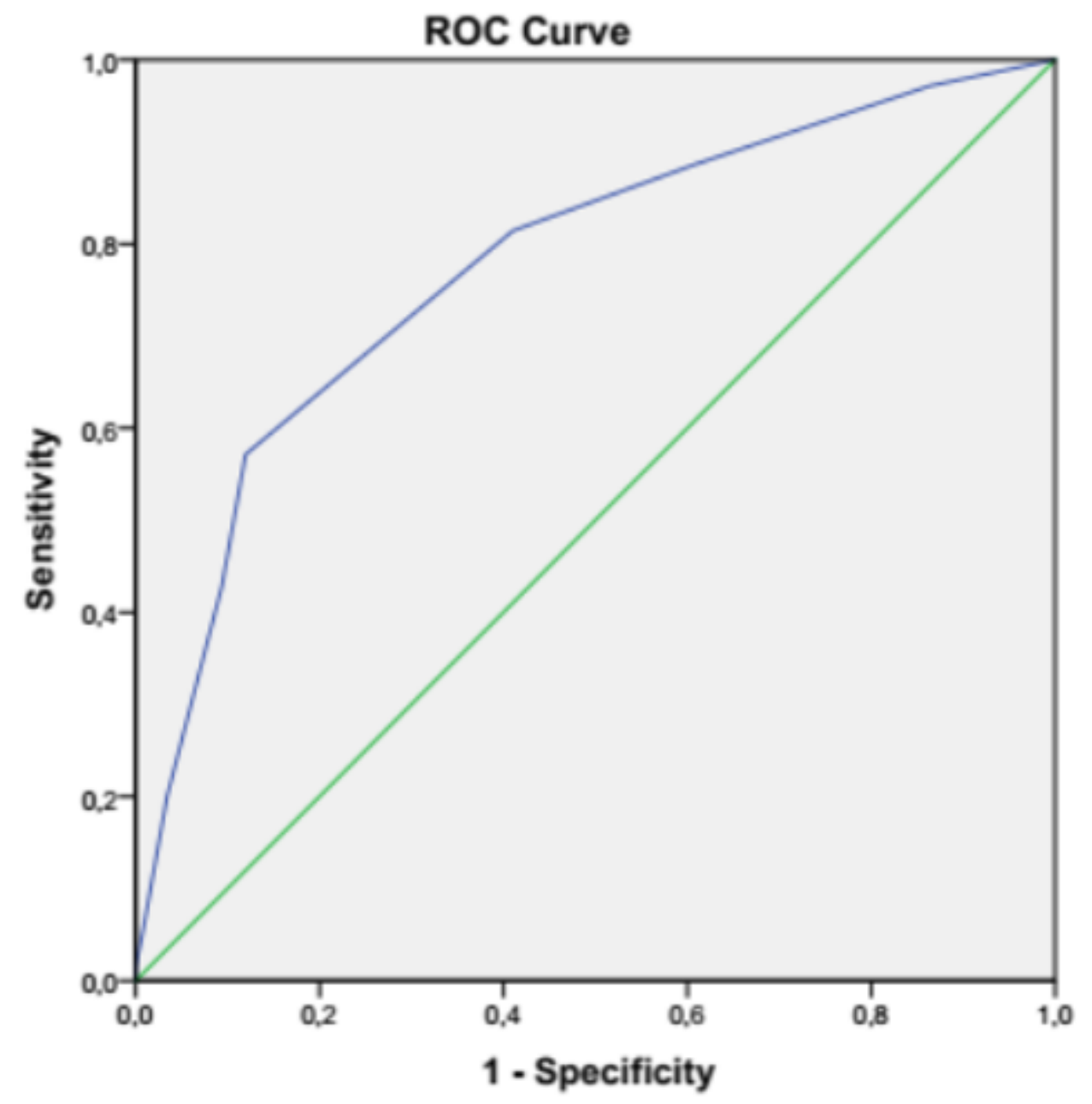

Figure 3

ROC curve of the scoring system.

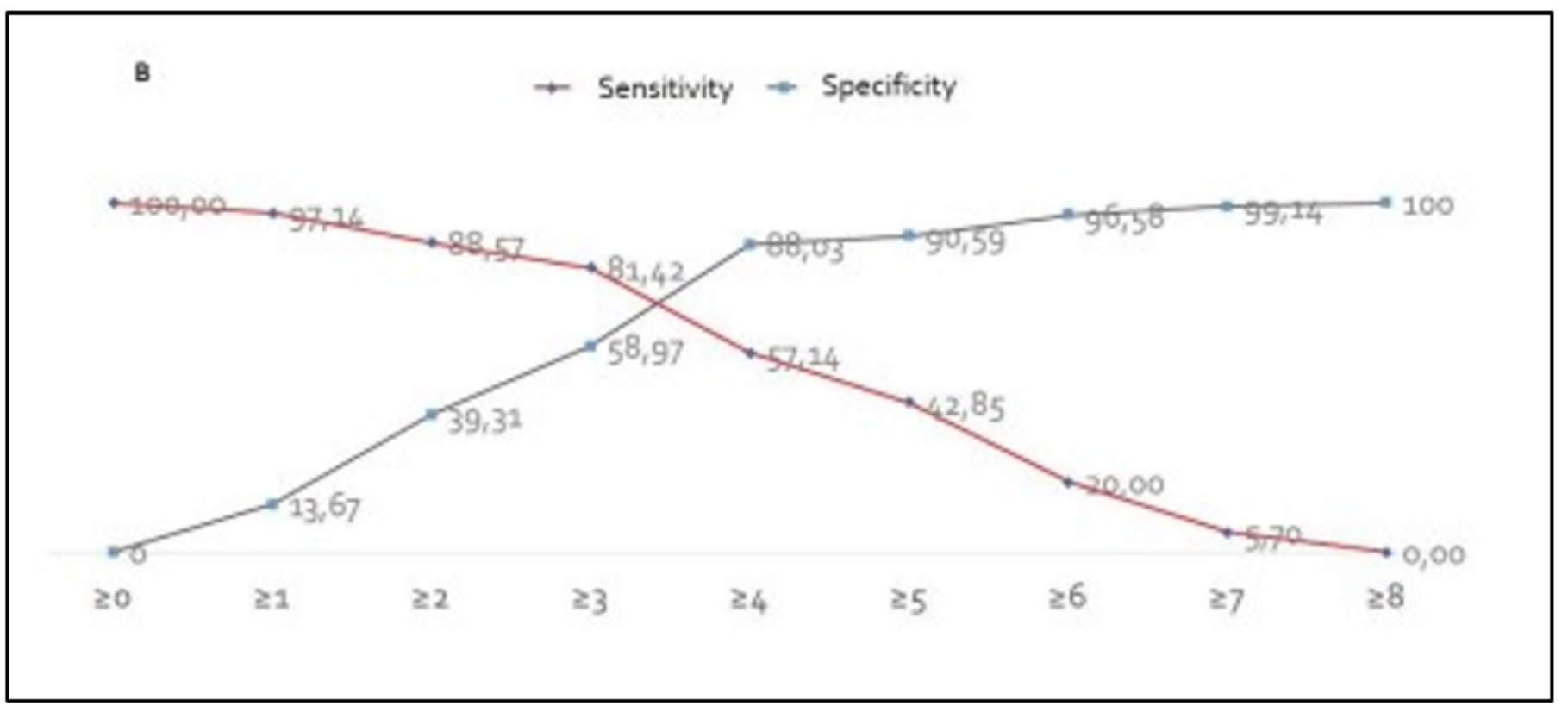

Page 19/20 
Figure 4

Cut-off curve between senstivity and specificity of the scoring system

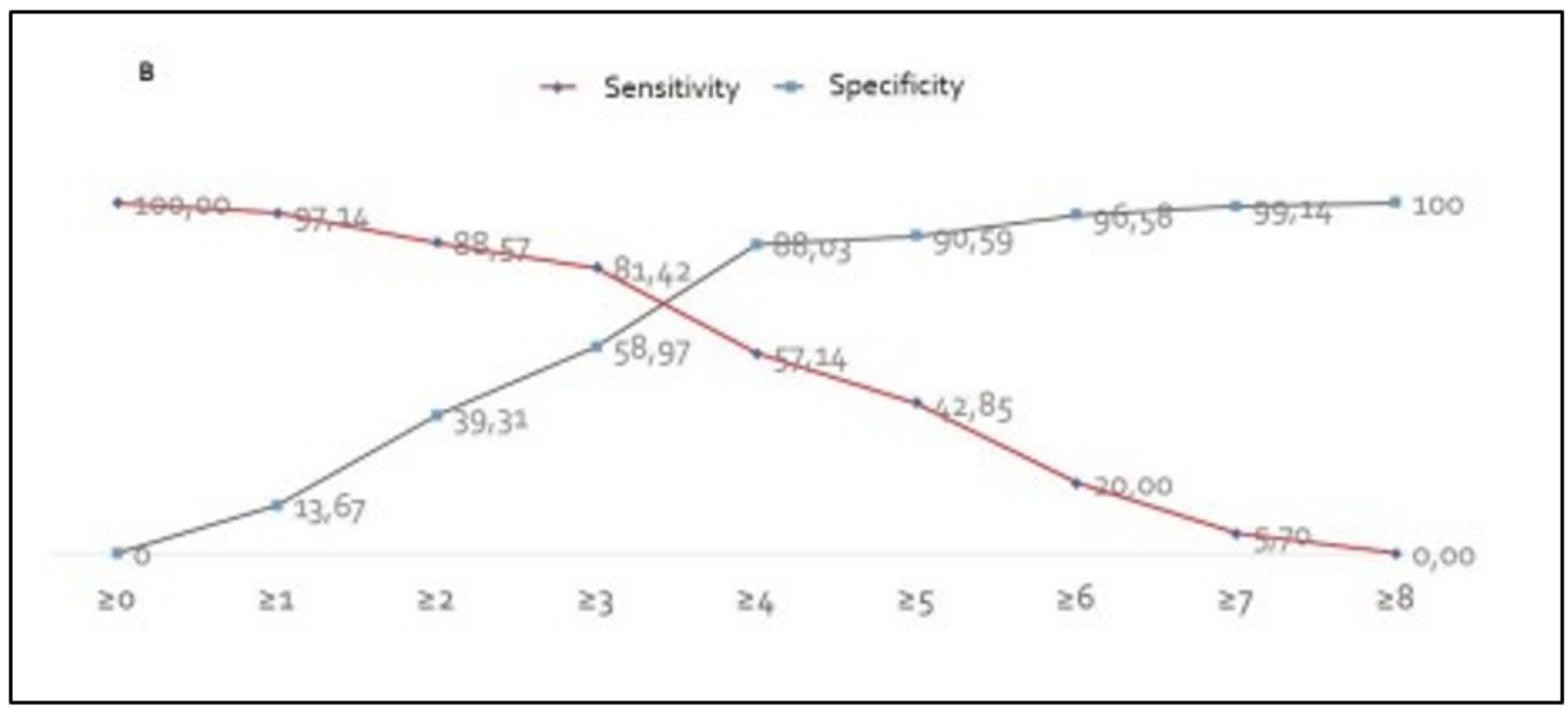

Figure 4

Cut-off curve between senstivity and specificity of the scoring system 